\title{
PENGARUH AGRESIVITAS PAJAK MENGGUNAKAN PROKSI BOOK TAX DIFFERENCE (BTD) DAN CASH EFFECTIVE TAX RATE (CETR) TERHADAP PENGUNGKAPAN CORPORATE SOCIAL RESPONSIBILITY (CSR) \\ (Studi Empiris pada Perusahaan Manufaktur yang Terdaftar di BEI Tahun 2015-2019) \\ 1); Nensi Yuniarti. Zs 2); Budi Astuti \\ 1) Department of Accountancy, Faculty of Economic and Business, Universitas Muhammadiyah Bengkulu \\ 2) Department of Accountancy, Faculty of Economic and Business, Universitas Muhammadiyah Bengkulu \\ Email: ${ }^{1)}$ nensiyuniarti@umb.ac.id; ${ }^{2)}$ budiastuti56@gmail.com
}

\section{How to Cite :}

Yuniarti, N. (2020). PENGARUH AGRESIVITAS PAJAK MENGGUNAKAN PROKSI BOOK TAX DIFFERENCE (BTD) DAN CASH EFFECTIVE TAX RATE (CETR) TERHADAP PENGUNGKAPAN CORPORATE SOCIAL RESPONSIBILITY (CSR) (STUDI EMPIRIS PADA PERUSAHAAN MANUFAKTUR YANG TERDAFTAR DI BEI TAHUN 2015-2019). EKOMBIS REVIEW: Jurnal IImiah Ekonomi Dan Bisnis, 8 (2). DOI:: https://doi.org/10.37676/ekombis.v8i2

\section{ARTICLE HISTORY}

Received [28 06 2020]

Revised [17 07 2020]

Accepted [30 07 2020]

\section{KEYWORDS}

Tax Aggressiveness,

Book Tax Difference,

Cash Effektive Tax Rate,

Corporate Social

Responsibility

This is an open access article under the $C C-B Y-S A$ license

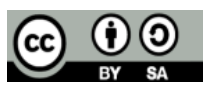

\section{ABSTRAK}

Penelitian ini bertujuan untuk menguji pengaruh agresivitas pajak terhadap pengungkapan tanggung jawab sosial perusahaan. Variabel independen yang digunakan dalam penelitian ini adalah agresivitas pajak dengan proksi Book-tax Difference (BTD), dan Cash Effective Tax Rate (CETR). Variabel dependen dalam penelitian ini adalah Corporate Social Responsibility (CSR).

Penelitian ini dilakukan pada perusahaan manufaktur yang tercatat di Bursa Efek Indonesia tahun 2015-2019, dengan menggunakan analisis resgresi berganda dan pengujian analisis sensitivitas. Teknik pengambilan sampel dilakukan melalui purposive sampling. Jumlah perusahaan sampel sebanyak 38 perusahaan dengan jumlah observasi sebanyak 152 observasi. Hasil penelitian menunjukkan bahwa agresivitas pajak dengan proksi BTD tidak berpengaruh terhadap CSR dimana hasil penelitian didapatkan signifikansi lebih besar dari 0,205 > 0,05, sedangkan agresivitas pajak dengan proksi CETR berpengaruh terhadap CSR, dengan hasil signifikansi $0,00<$ 0,05 . Temuan lain dalam penelitian ini mengungkapkan bahwa perusahaan yang melakukan agresivitas pajak cenderung untuk melakukan pengungkapan tanggung jawab sosial yang lebih 
luas untuk mendapat dukungan positif dari masyarakat dan lingkungan untuk mempertahankan eksistensinya.

\section{ABSTRACT}

This study aims to examine the effect of tax aggressiveness on disclosure of corpor ate social responsibility. The independent variables used in this study are tax aggressiveness with Book-Tax Difference (BTD), and Cash Effective Tax Rate (CETR) proxy. The dependent variable in this study is Corporate Social Responsibility (CSR).

This research was conducted on manufacturing companies listed on the Indonesia Stock Exchange in 2015-2019, using multiple regression analysis and sensitivity analysis testing. The sampling technique is done through purposive sampling. The number of sample companies was 38 companies with 152 observations.

The results showed that tax aggressiveness with the BTD proxy does not also affect CSR where the research results obtained significance of greater than 0.205> 0.05. While the tax aggressiveness with the CETR proxy affects CSR, with a significance of $0.00<0.05$. Other findings in this study reveal that companies that carry out tax aggressiveness tend to disclose broader social responsibilities to get positive support from the community and the environment to maintain their existence.

\section{PENDAHULUAN}

Pajak merupakan salah satu pendapatan yang diterima oleh pemerintah dan diperoleh dari masyarakat yang digunakan untuk pembangunan suatu negara, baik untuk infrastruktur maupun untuk menunjang kesejahteraan masyarakat suatu negara. Pajak dipungut berdasarkan hukum-hukum yang berlaku di suatu negara dan merupakan sumber penerimaan yang penting serta krusial bagi suatu negara.

Namun, lain halnya pajak bagi suatu perusahaan. Pajak bagi suatu perusahaan merupakan salah satu beban yang dapat menurunkan tingkat pendapatan serta keuntungan suatu perusahaan. Oleh karena itu perusahaan banyak melakukan tindakan agresivitas pajak. Agaresivitas pajak merupakan suatu hal yang umum dilakukan di kalangan perusahaan besar di seluruh dunia meskipun sampai saat ini masih menjadi perdebatan. Menurut Sumarsan (2013) dalam Diah, dkk (2015), tindakan agresivitas pajak yang dilakukan melalui strategi perencanaan pajak pada umumnya berusaha untuk menghindari sanksi akibat dari penerapan pajak yang melanggar peraturan dan perundang-undangan perpajakan di Indonesia, namun perencanaan pajak merupakan penerapan kegiatan-kegiatan perusahaan terhadap aturan dan perundangundangan perpajakan yang berlaku guna mengecilkan beban pajak perusahaan. Agresivitas pajak adalah suatu skema transaksi yang ditujukan untuk meminimalkan beban pajak dengan memanfaatkan kelemahan-kelemahan (loophole) ketentuan perpajakan suatu negara sehingga ahli pajak menyatakan legal karena tidak melanggar aturan perpajakan (Darussalam dan Danny, 2009). Tindakan ini menjadi perhatian publik karena tidak sesuai dengan harapan masyarakat dan juga dapat merugikan negara. Perusahaan yang melakukan agresivitas pajak ditandai dengan rendahnya transparansi terhadap informasi keuangan perusahaan. Dalam hal ini agresivitas pajak 
menyebabkan kerusakan reputasi perusahaan karena pajak yang dibayarkan kepada negara tersebut akan dialokasikan untuk kesejahteraan masyarakat (Nanda, dkk (2015). Oleh karena itu perusahaan yang melakukan agresivitas pajak tidak memperoleh legitimasi.

Dalam teori legitimasi diungkapkan oleh Hurst (1970) dalam Lanis dan Richardson (2013) mengindikasikan bahwa ada ketidaksesuaian antara tindakan perusahaan dengan harapan masyarakat, manajemen perusahaan akan melakukan pengungkapan melalui laporan tahunan untuk memperoleh legitimasi. Teori tersebut juga mengungkapkan bahwa informasi pengungkapan dalam laporan tahunan berbentuk laporan pengungkapan Corporate Social Responsibility (CSR) digunakan untuk mengurangi konsentrasi publik dan membantu perusahaan mendapatkan legitimasi. Maka dari itu, perusahaan melakukan agresivitas pajak guna merubah pandangan negatif masyarakat dalam memandang suatu perusahaan. Dimana selama ini stigma masyarakat lebih condong ke arah yang negatif, perusahaan dianggap hanya mencari keuntungan tanpa melihat dan memiliki tanggung jawab sosial terhadap masyarakat.

Penelitian ini sebelumnya telah diteliti oleh Rizki dan Didik (2017), pada perusahaan manufaktur yang terdaftar di BEI tahun 2013-2016. Dimana dalam penelitiannya diketahui bahwa agresivitas pajak berpengaruh positif terhadap Corporate Social Responsibility dengan alat ukur menggunakan proksi ETR (Effective Tax Rate). Namun hasil yang berbeda ditemukan pada penelitian yang dilakukan oleh Natasya dan Abdul (2014), yang hasil penelitiannya menyatakan bahwa agresivitas pajak tidak berpengaruh terhadap Corporate Social Responsibility. Hal ini menunjukkan bahwa perusahaan yang memiliki agresivitas pajak yang rendah akan cenderung mengungkapkan informasi corporate social responsibility (CSR) yang lebih besar untuk mendapatkan simpati masyarakat dan melaksanakan kebijakan pemerintah dalam bidang sosial dan ekonomi.

Dengan adanya perbedaan hasil penelitian tersebut, maka peneliti bermaksud untuk melakukan penelitian ulang dengan penggunaan variabel yang sama, namun dengan penggunaan proksi pada perhitungan agresivitas pajak yang berbeda. Sehingga bisa disimpulkan bahwa Penelitian ini bertujuan untuk menguji kembali apakah agresivitas pajak dengan menggunakan proksi book tax difference (BTD) dan proksi cash effective tax rate (CETR) berpengaruh terhadap pengungkapan corporate social responsibility (CSR) pada Perusahaan Manufaktur yang Terdaftar di BEI Tahun 2015-2019.

\section{LANDASAN TEORI}

\section{Teori Legitimasi (Legitimacy Theory)}

Gray et. al, (1996) dalam Reny dan Denies (2012), berpendapat bahwa legitimasi merupakan ".... a system-oriented view of organisation and society ... permits us to focus on the role of information and disclosure in relationship between organisations, the state, individualsand group".

Definisi tersebut mengisyaratkan, bahwa legitimasi merupakan sistem pengelolaan perusahaan yang berorientasi pada keberpihakan terhadap masyarakat (society) pemerintah, individu dan kelompok masyarakat. Untuk itu sebagai suatu sistem yang mengedepankan keberpihakan kepada masyarakat, operasi perusahaan harus kongruen dengan harapan masyarakat.

\section{Teori Stakeholder ( Stakeholder Theory)}

Teori stakeholder menyatakan bahwa perusahaan bukanlah entitas yang hanya beroperasi untuk kepentingan sendiri namun harus memberikan manfaat bagi stakeholdernya (pemegang saham, kreditor, konsumen, supplier, pemerintah, masyarakat, analisis, dan pihak 
lain (Natasha, 2014). Dengan kata lain perusahaan dapat beroperasi membutuhkan bantuan dari pihak luar salah satunya adalah dukungan dari masyarakat.

Grat et al (1997) dalam Rizki dan Didik (2017), menyatakan bahwa dalam teori stakeholder merupakan pendekatan berbasis tekanan pasar (market forces approach) dimana penyediaan atau penarikan atas sumber ekonomi akan menentukan tipe pengungkapan sosial dan lingkungan pada titik waktu tertentu. Disamping itu teori stakeholder mengabaikan pengaruh masyarakat luas terhadap penyediaan informasi dalam laporan keuangan, termasuk keberadaan hukum dan regulasi yang menghendaki adanya pengungkapan informasi tertentu.

\section{Agresivitas Pajak}

Menurut Darussalam dan Septriadi dalam Diah, dkk (2015), agresivitas pajak atau perencanaan pajak adalah suatu skema transaksi yang ditujukan untuk meminimalkan beban pajak dengan memanfaatkan kelemahan-kelemahan (loophole) ketentuan perpajakan suatu negara sehingga ahli pajak menyatakan legal karena tidak melanggar aturan perpajakan.

Ada beberapa cara dalam mengukur agresivitas pajak, seperti menggunakan proksi Effective Tax Rates (ETR), Book-tax Difference (BTD), Discretionary Permanent BTD's (DTAX), Unrecognize Tax Benefit, Tax Shelter Activity, Marginal Tax Rate, dan Cash Effective Tax Rate (CETR). Proksi Book-tax Difference (BTD) digunakan dalam penelitian ini karena mencerminkan total perbedaan antara laba akuntansi dan laba fiskal. Perhitungan yang digunakan :

$$
\mathrm{BTD}=\frac{\text { Laba Akuntansi }- \text { Laba Fiskal }}{\text { Total Aset Bersih }}
$$

Sedangkan proksi Cash Effective Tax Rate (CETR), digunakan karena menggambarkan presentase total pembayaran pajak penghasilan yang dibayarkan perusahaan dari seluruh total pendapatan sebelum pajak. Rumus untuk menghitung CETR disini adalah:

$$
\mathrm{CETR}=\frac{\text { Pembayaran Pajak Penghasilan }}{\text { Laba Sebelum Pajak }}
$$

\section{Corporate Social Responsibility (CSR) Disclosure}

Pengungkapan tanggungjawab sosial perusahaan (CSR-disclosure) merupakan proses pengkomunikasian dampak sosial dan lingkungan dari kegiatan ekonomi organisasi terhadap kelompok khusus yang berkepentingan dan terhadap masyarakat secara keseluruhan. Selain itu pengungkapan CSR dipandang sebagai sarana yang digunakan oleh menajemen perusahaan dalam berinteraksi dengan masyarakat yang lebih luas untuk mempengaruhi presepsi.

\section{Pengembangan Hipotesis}

\section{Pengaruh Agresivitas Pajak Terhadap Pengungkapan Corporate Social Responsibility dengan Proksi Book-tax Difference (BTD)}

Menurut Khurana dan Moser (2009), mendefinisikan agresivitas pajak sebagai tax planning perusahaan melalui aktivitas tax avoidance atau tax sheltering. Ini merupakan keinginan perusahaan untuk meminimalkan beban pajak melalui aktivitas tax planning dengan tujuan memaksimalkan nilai perusahaan. Aktivitas tax planning dilakukan melalui cara yang legal, ilegal, maupun dengan cara kedua-duanya. Penggunaan proksi book tax difference dalam perhitungan agresivitas pajak karena mencerminkan total perbedaan antara laba akuntansi dan laba fiskal. 
Dari penelitian yang dilakukan oleh Khurana dan Moser (2009), dengan menggunakan proksi Book-tax Difference (BTD) menyatakan bahwa hal tersebut berpengaruh positif terhadap agresivitas pajak. Berdasarkan uraian di atas maka hipotesis yang diajukan oleh peneliti untuk membuktikan penelitian ini adalah:

H1 : Agresivitas pajak dengan proksi Book-tax Difference (BTD) berpengaruh terhadap Corporate Social Responsibility (CSR).

\section{Pengaruh Agresivitas Pajak Terhadap Pengungkapan Corporate Social Responsibility dengan Proksi Cash Effective Tax Rate (CETR)}

Menurut Frank et al (2009) dalam Dewi dan Dwi (2010), tindakan pajak agresif adalah suatu tindakan yang ditujukan untuk menurunkan laba kena pajak melalui perencanaan pajak baik menggunakan cara yang tergolong atau tidak tergolong tax evasion. Dari penelitian yang dilakukan oleh Dewi dan Dwi (2010), dengan menggunakan proksi Cash Effective Tax Rate (CETR) menyatakan bahwa hal tersebut berpengaruh positif terhadap agresivitas pajak. Berdasarkan uraian di atas maka hipotesis yang diajukan oleh peneliti untuk membuktikan penelitian ini adalah:

H2 : Agresivitas pajak dengan proksi Cash Effective Tax Rate (CETR) berpengaruh terhadap Corporate Social Responsibility (CSR).

\section{METODE PENELITIAN}

\section{Metode Analisis}

Metode analisis data dalam penelitian ini menggunakan statistik deskriptif, dimana statistik deskriptif digunakan untuk memberikan deskripsi suatu data yang dilihat dari rata-rata (mean), standar deviasi, dan maksimum minimum. Selain itu dalam penelitian ini juga menggunakan pengujian analisis statistik, uji asumsi klasik, dan model persamaan regresi berganda.

Analisis regresi berganda digunakan untuk melihat pengaruh variabel independen terhadap variabel dependen. Persamaan regresi yang digunakan adalah :

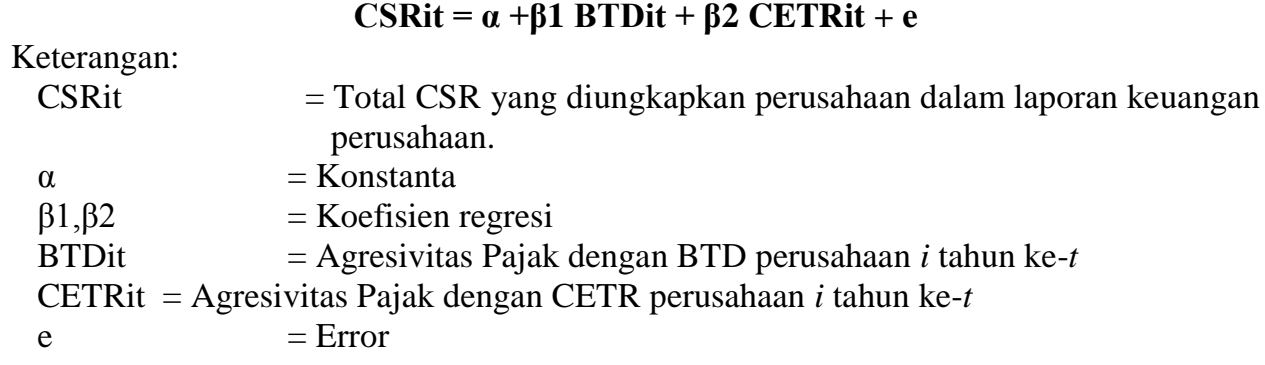

\section{Pembahasan}

\section{HASIL DAN PEMBAHASAN}

Dalam penelitian ini, populasi yang digunakan adalah seluruh perusahaan manufaktur yang terdaftar di Bursa Efek Indonesia (BEI) tahun 2015-2019 serta yang memenuhi kriteria. Sedangkan teknik pengambilan sampel dalam penelitian ini menggunaka metode purposive sampling.

Dengan kriteria yang telah ditetaplan maka jumlah sampel dalam penelitian ini berjumlah 38 perusahaan dengan jumlah observasi sebanyak 152 observasi.

Berikut disajikan hasil pengujian linear berganda dalam penelitian ini: 
Hasil Uji Linear Berganda

\begin{tabular}{|c|c|c|c|c|c|}
\hline \multirow[t]{2}{*}{ Model } & \multicolumn{2}{|c|}{$\begin{array}{l}\text { Unstandardized } \\
\text { Coefficients }\end{array}$} & \multirow{2}{*}{$\begin{array}{c}\begin{array}{c}\text { Standardiz } \\
\text { ed Coefficients }\end{array} \\
\text { Beta }\end{array}$} & \multirow[t]{2}{*}{$\mathrm{t}$} & \multirow[t]{2}{*}{ Sig. } \\
\hline & B & Std. Error & & & \\
\hline (Constant) & .078 & .004 & & 20.904 & .000 \\
\hline BTD1 & -.073 & .058 & -.093 & -1.274 & .205 \\
\hline CETR1 & -.002 & .000 & -.574 & -7.954 & .000 \\
\hline
\end{tabular}

a.

Dependent

Variable: CSR1

$$
\begin{aligned}
& \text { Model : CSRit }=\alpha 0+\beta 1 \text { ETRit }+\boldsymbol{\beta 2} \text { BTDit }+\beta 3 \text { CETRit }+\mathbf{e} \\
& =0,078-0,066 \text { ETRit - 0,073 BTDit - 0,002 CETRit + e }
\end{aligned}
$$

Berdasarkan persamaan regresi linier berganda tersebut, maka dapat dilihat bahwa nilai konstanta sebesar 0,078 dapat diartikan bahwa apabila variabel independen, yaitu agresivitas pajak dengan proksi Book-tax Difference (BTD), dan Cash Effective Tax Rate (CETR) dianggap konstan (bernilai 0), maka Corporate Social Responsibility (CSR) akan naik sebesar 0,078. Nilai konstanta positif menunjukan pengaruh positif antara variabel independen dengan variabel dependen, yaitu agresivitas pajak dengan proksi Book-tax Difference (BTD), dan Cash Effective Tax Rate (CETR) mengalami peningkatan, Corporate Social Responsibility (CSR) akan mengalami peningkatan juga.

Hasil pengujian kelayakan model (Uji F) dapat dilihat pada tabel berikut:

\begin{tabular}{|c|c|c|c|c|c|c|}
\hline & \multicolumn{6}{|c|}{ ANOVA $^{b}$} \\
\hline & Model & $\begin{array}{l}\text { Sum of } \\
\text { Squares }\end{array}$ & df & $\begin{array}{l}\text { Mean } \\
\text { Square }\end{array}$ & $\mathrm{F}$ & Sig. \\
\hline \multirow[t]{3}{*}{1} & Regression & .074 & 3 & .025 & 22.640 & $.000^{\mathrm{a}}$ \\
\hline & Residual & .135 & 124 & .001 & & \\
\hline & Total & .209 & 127 & & & \\
\hline
\end{tabular}

\section{Hasil Uji F}

a. Predictors: (Constant), BTD1, ETR1

b. Dependent Variable: CSR1

Berdasarkan tabel diatas hasil uji $\mathrm{F}$ menunjukkan bahwa nilai $\mathrm{F}_{\text {hitung }}$ yang terdapat dalam tabel ANOVA yaitu sebesar 22,640 dengan signifikansi 0,000. Sementara $F_{\text {tabel }}$ dari df (3:151) sebesar 2,66 sehingga $F_{\text {hitung }}>F_{\text {tabel }}$ yakni 22,640 >2,66 dan nilai signifikan juga lebih kecil dari probabilitas 5\%. Sehingga dapat disimpulkan bahwa model regresi dalam penelitian ini fit dan berpengaruh secara simultan atau bersama-sama dari seluruh variabel independen yakni Book-tax Difference, dan Cash Effective Tax Ratet terhadap variabel dependen Corporate Social Responsibility.

Hasil uji koefisien determinasi $\left(\mathrm{R}^{2}\right)$ dapat dilihat pada tabel berikut ini :

188 | Nensi Yuniarti. Zs; Budi Astuti; Pengaruh Agresivitas Pajak Menggunakan... 
Hasil Uji Koefisien Determinasi

Model Summary

\begin{tabular}{|c|c|c|c|c|}
\hline Model & $\mathrm{R}$ & $\begin{array}{r}\mathrm{R} \\
\text { Square }\end{array}$ & $\begin{array}{l}\text { Adjusted R } \\
\text { Square }\end{array}$ & $\begin{array}{l}\text { Std. Error } \\
\text { of the Estimate }\end{array}$ \\
\hline 1 & $\begin{array}{r}.595 \\
\mathrm{a}\end{array}$ & .354 & .338 & .03303 \\
\hline
\end{tabular}

a. Predictors: (Constant), BTD1, ETR1

b. Dependent Variable: CSR1

Berdasarkan data diatas adapun analisis determinasi berganda diketahui presentase pengaruh variabel bebas terhadap variabel terikat yang ditunjukan dengan nilai Adjusted $R$ Square sebesar 0,338 maka koefisien determinasi berganda $0,338 \times 100 \%=33,8 \%$ dan sisanya $100 \%-33,8 \%=66,2 \%$. Hal ini berarti naik turunnya variabel terikat yaitu Corporate Social Responsibility (CSR) dipengaruhi oleh variabel bebas yaitu agresivitas pajak dengan proksi Book-tax Difference (BTD), dan Cash Effective Tax Rate (CETR) sebesar 33,8\%. Sedangkan sisanya sebesar $66,2 \%$ dipengaruhi oleh variabel lain yang tidak diteliti dalam penelitian ini.

Sedangkan untuk hasil uji parsial (uji t) dapat dilihat pada tabel berikut ini:

\section{Hasil Uji Parsial (Uji t)}

Coefficients $^{\mathrm{a}}$

\begin{tabular}{|l|r|r|r|r|r|}
\hline \multirow{2}{*}{ Model } & \multicolumn{2}{|c|}{$\begin{array}{c}\text { Unstandardized } \\
\text { Coefficients }\end{array}$} & \multicolumn{1}{|c|}{$\begin{array}{c}\text { Standardized } \\
\text { Coefficients }\end{array}$} & \multirow{2}{*}{$\mathrm{t}$} & Sig. \\
\cline { 2 - 4 } & $\mathrm{B}$ & $\begin{array}{c}\text { Std. } \\
\text { Error }\end{array}$ & \multicolumn{1}{|c|}{ Beta } & & \\
\hline (Constant) & .078 & .004 & & 20.904 & .000 \\
BTD1 & -.073 & .058 & -.093 & -1.274 & .205 \\
CETR1 & -.002 & .000 & -.574 & -7.954 & .000 \\
\hline
\end{tabular}

CSR1

a. Dependent Variable:

Untuk pengujian pada hipotesis pertama dimana agresivitas pajak diukur dengan proksi Book-tax Difference (BTD) menunjukkan hasil dimana agresivitas pajak dengan proksi Book-tax Difference (BTD) tidak berpengaruh terhadap pengungkapan Corporate Social Responsibility (CSR) pada perusahaan manufaktur yang terdaftar di Bursa Efek Indonesia tahun 2015-2019. Hal ini dapat dilihat bahwa nilai $\beta$ sebesar -0.073 , nilai t sebesar $-1,274$ dan nilai signifikansi sebesar 0,205 dimana hal tersebut memiliki tingkat signifikansi > 0,05. Dengan nilai $\beta$ sebesar -0.073 artinya apabila agresivitas pajak meningkat satu- satuan unit maka Corporate Social Responsibility (CSR) meningkat sebesar -0.073 .

Hal ini sejalan dengan penelitian yang dilakukan oleh Nanda, dkk (2015), dimana hasil pengujian menggunakan proksi Book-tax Difference (BTD) yang menunjukkan hasil bahwa agresivitas pajak proksi Book-tax Difference (BTD) berpengaruh secara negatif terhadap pengungkapan Corporate Social Responsibility (CSR). Mereka mengungkapkan bahwa di Indonesia agresivitas pajak belum dipublikasikan seperti di negara lain yang menggunakan sistem pengurutan perusahaan dari tingkat agresivitas pajaknya. 
Sedangkan untuk pengujian hipotesis kedua menyatakan bahwa agresivitas pajak dengan proksi Cash Effective Tax Rate (CETR) berpengaruh terhadap pengungkapan Corporate Social Responsibility (CSR), terhadap perusahaan manufaktur yang terdaftar di Bursa Efek Indonesia (BEI) tahun 2015-2019. Agresivitas pajak dengan proksi Cash Effective Tax Rate (CETR) didapat melalui perbandingan antara pembayaran sebelum pajak dengan laba sebelum pajak. Hasil penelitian yang diperoleh didapatkan hasil $\beta$ sebesar $-0,002$, nilai t sebesar $-7,954$ dan nilai signifikansi sebesar 0,000 dimana tingkat signifikansi < 0,05. Hal tersebut menandakan bahwa variabel Cash Effective Tax Rate (CETR) berpengaruh negatif signifikan terhadap Corporate Social Responsibility (CSR). Nilai Cash Effective Tax Rate (CETR) yang rendah menunjukkan tindakan agresivitas pajak yang dilakukan perusahaan tinggi. Dapat disimpulkan bahwa semakin tinggi nilai agresivitas pajak perusahaan (CETR yang semakin rendah) maka semakin luas pengungkapan Corporate Social Responsibility (CSR) perusahaan, artinya apabila agresivitas pajak meningkat satu- satuan unit maka Corporate Social Responsibility (CSR) meningkat sebesar 0,002 .

\section{KESIMPULAN DAN SARAN}

\section{Kesimpulan}

Berdasarkan hasil yang diperoleh dari pengolahan dan analisis data maka dapat diambil kesimpulan sebagai berikut:

1. Agresivitas pajak dengan proksi Book-tax Difference (BTD) tidak berpengaruh terhadap pengungkapan Corporate Social Responsibility. Nilai signifikansi dari pengujian didapatkan sebesar 0, 205 dimana nilai tersebut lebih besar dari 0,05.

2. Agresivitas pajak dengan proksi Cash Effective Tax Rate (CETR) berpengaruh terhadap pengungkapan Corporate Social Responsibility. Dari hasil pengujian didapatkan signifikansi 0,00 dimana nilai signifikansi tersebut $<0,05$ sehingga agresivitas pajak dengan proksi Cash Effective Tax Rate (CETR) mempengaruhi adanya pengungkapan Corporate Social Responsibility.

\section{Saran}

Penelitian ini pada dasarnya bertujuan untuk menguji secara empiris mengenai pengaruh agresivitas pajak terhadap pengungkapan Corporate Social Responsibility (CSR) dengan menggunakan proksi Book-tax Difference (BTD) dan Cash Effective Tax Rate (CETR). Dalam hal ini, maka peneliti mengajukan beberapa saran dalam upaya perbaikan penulisan untuk penelitian selanjutnya antara lain: untuk penelitian selanjutnya disarankan memperbesar sampel penelitian tidak hanya terbatas pada perusahaan manufaktur saja, tapi juga pada perusahaan sektor lain seperti pertambangan, perkebunan, keuangan dan non keuangan, serta menggunakan proksi penelitian yang lain untuk menguji agresivitas pajak ini.

\section{DAFTAR PUSTAKA}

Darussalam., \& Danny, S. (2009). Tax Avoidance, Tax Planning, Tax Evasion, dan Anti Avoidance Rule.

(Online). (http://www.ortax.org/ortax/?mod=issue\&page=show\&id=36\&hlm=2)(diakses pada tanggal 6 November 2018). 
Diah, M. R., Lilik, H., \& Elin, E. S. (2015). Agresivitas Pajak pada Perusahaan Publik Indonesia yang Melakukan Pengungkapan Corporate Social Responsibility. Jurnal Riset. Universitas Mataram.

Global Reporting Initiative. GRI Sustainability Reporting Guidelines G4. Diambil dari www.globa;reporting.org. Diakses tanggal 7 November 2018.

Imam, G. (2013). Analisis Multivariate dengan Program IBM SPSS 21. Semarang : Badan Penerbit Fakultas Ekonomi Universitas Diponegoro.

Intan, A. U., \& Abdul, R., (2015). Pengaruh Agresivitas Pajak Terhadap Pengungkapan Corporate Social Responsibility : untuk Menguji Teori Legitimasi. Jurnal Riset. Fakultas Ekonomika dan Bisnis Universitas Diponegoro, Semarang.

Lanis, R., \& Richardson, G. (2013). Corporate Social Responsibility and Tax Aggressiveness: An empirical analysis. Accounting, Auditing \& Accountability Journal Vol. 26 No. 1. Emerald Group Publishing.

Marghalina, B. F., Syafi'i., \& Kusni, H. (2018). Pengaruh Agresivitas Pajak Terhadap Pengungkapan Corporate Social Responsibility. Jurnal Ekonomi Equity Volume 4 Issue 2. Universitas Bhayangkara.

Nanda, I. N., Nila, F. N., \& Agung, D. (2015). Pengaruh Agresivitas Pajak Terhadap Pengungkapan Corporate Social Responsibility (CSR) (Studi pada Perusahaan yang Terdaftar di Indeks SRI-KEHATI tahun 2011-2013). Jurnal Perpajakan Vol. 5 No.2. Fakultas Ilmu Administrasi Universitas Brawijaya, Malang.

Natasya, E. O. (2014). Pengaruh Agresivitas Pajak Terhadap Pengungkapan Corporate Social Responsibility : untuk Menguji Teori Legitimasi. Skripsi (Tidak Dipublikasikan). Semarang : Universitas Diponegoro.

Rizki, A., \& Didik, A. (2017). Pengaruh Agresivitas Pajak Terhadap Pengungkapan Corporate Social Responsibility. Jurnal Riset. Semarang : Universitas Diponegoro.

Winda, P., \& Pancawati, H. (2015). Pengaruh Agresivitas Pajak dan Media Exksplosure Terhadap Pengungkapan Corporate Social Responsibility. Jurnal Riset. Fakultas Ekonomika dan Bisnis Universitas Stikubang. 